\title{
Recovery of microphytobenthos and benthic functions after sediment deposition
}

\author{
Fredrik Larson ${ }^{1,2}$, Kristina Sundbäck ${ }^{1, *}$ \\ ${ }^{1}$ Department of Marine Ecology, University of Gothenburg, 40530 Göteborg, Sweden \\ ${ }^{2}$ Present address: Swedish Agency for Marine and Water Management, 40439 Göteborg, Sweden
}

\begin{abstract}
Recovery of microphytobentos (MPB) and benthic processes were followed during $23 \mathrm{~d}$ after sediment deposition simulating the effects of $1 \mathrm{wk}$ of nearby dredging or construction work. Cores of natural intact sediment in an outdoor flow-through system were exposed to daily depositions of $1.5 \mathrm{~mm}$ fine-grained sediment over $7 \mathrm{~d}$ (total load $10.5 \mathrm{~mm}$ ). Porosity, chlorophyll a (chl $a_{\text {i }}$ proxy for MPB biomass), denitrification and sediment-water fluxes of oxygen and inorganic nutrients were measured during day and night on 6 occasions. After deposition stopped, chl $a$ in the uppermost $3 \mathrm{~mm}$ of the sediment had decreased to $25 \%$ of that in the controls, started to increase linearly, probably due to upward migration of diatoms, but did not converge with the control cores in the course of the experiment. The linear increase of chl a indicated a recovery of algal biomass after $\sim 50 \mathrm{~d}$. The proportion of large sigmoid diatoms increased in the deposition cores and this change in MPB composition remained over the $23 \mathrm{~d}$. Deposition resulted in higher porosity and increased flaking of the newly established algal mat. Deposition generally increased release or decreased uptake of nutrients, though effects on nitrate flux and denitrification were less clear. Although alga-related functions (oxygen production and nutrient fluxes in light) recovered faster than algal biomass, the faster recovery of the integrated system function in the dark reflected the impact of deposition on MPB. Sediment deposition in microtidal areas may imply disturbances for MPB, threatening the food supply for grazers and deposit feeders, and, in the end, fish that use the shallow areas as nurseries.
\end{abstract}

KEY WORDS: Microphytobenthos - Sediment deposition · Oxygen flux - Nutrient flux · Denitrification · Resilience

\section{INTRODUCTION}

Shallow coastal areas provide a multitude of ecological goods and services (Costanza et al. 1997, Söderqvist et al. 2005), but are today exposed to a range of anthropogenic impacts. One such impact is the increased deposition of sediment caused by dredging, construction works in or close to the water, and changed land use (e.g. Miller et al. 2002, Thrush et al. 2004, Borja et al. 2010). Several studies on the effect of such physical disturbances on benthic macrofauna have found that recovery time of both abundance and species composition varies, but often exceeds 1 yr (Boyd et al. 2003, Dernie et al. 2003, Thrush et al. 2003, Lundquist et al. 2004). Recovery has been found to be controlled by a combination of physical end ecological factors operating on different temporal and spatial scales (Norkko et al. 2006, Thrush et al. 2008), such as the ability of the organisms to migrate to the sediment surface (e.g. Schratzberger et al. 2000). Faunal recovery rate is also well correlated with the availability of food resources (Stocks \& Grassle 2001), emphasising the crucial role of the microscopic organisms that consti- 
tute the base of the food webs of shallow-water sediments. Despite this obvious dependency on lower trophic levels there are surprisingly few studies that have considered the effects of sediment deposition on microbenthic populations at the sediment-water interface (Wulff et al. 1997, Schratzberger et al. 2000), let alone functions controlled by them (Rodil et al. 2011).

In shallow-water sediments, microbenthic organisms drive central ecosystem processes, such as primary production, decomposition and remineralisation, and therefore play a key role in biogeochemical cycling (e.g. Hochard et al. 2010 and references therein). In photic sediments, the autotrophic component consisting of microalgae and cyanobacteria (microphytobenthos, MPB) often dominates these communities (Paerl \& Pinckney 1996). MPB are not only important primary producers (Underwood \& Kromkamp 1999, Haese \& Pronk 2011), but also control sediment-water nutrient fluxes, often turning sediment into nutrient sinks (Sundbäck et al. 2004 and references therein), and bacterial nitrogen turnover (Risgaard Petersen 2003). They also function as eco-engineers, stabilising sediments through the production of extracellular polymeric substances (EPS) (Yallop et al. 1994, Underwood \& Smith 1998). Since adjacent systems are dependent on shallow areas for recruitment and food supply, their function is even more important in a wider perspective. Increased knowledge of the sensitivity and resilience of these microbenthic communities, as well as processes controlled by them, is important for the effective management of coastal resources.

One important finding regarding stressor effects on shallow-water benthic communities is that MPB substantially enhance the resilience of sediment systems. Particularly benthic diatoms, because of their obviously high resistance (tolerance) to stressors such as hypoxia, $\mathrm{H}_{2} \mathrm{~S}$ and low levels of toxicants, contribute to the rapid recovery of crucial ecosystem functions (Piehler et al. 2003, Alsterberg et al. 2007, Larson et al. 2007, Larson \& Sundbäck 2008). The mechanism is that MPB rapidly re-oxygenate the sediment surface, aiding the recovery of other important compartments and processes (e.g. Underwood \& Paterson 1993, Sundbäck et al. 2007, Larson \& Sundbäck 2008, Petersen et al. 2009). Deposition of sediment is a disturbance that differs from the stressors mentioned above in that it affects the most important resource of MPB, namely light. Endurance of periods of darkness and rapid upward migration therefore become important traits. Wulff et al. (1997) found that the algal, meiofaunal and bacterial communities of a sandy sediment recovered after $2.5 \mathrm{~mm}$ deposition of silt within $8 \mathrm{~d}$. This result suggests that, as long as the deposited sediment layer (void of live MPB) is thin, rapid upward migration can quickly restore the algal community and its function at the sediment-water interface.

The aim of our experiment was to study the resilience of a silty, illuminated sediment and its functions after sediment deposition simulating short-term (ca. $1 \mathrm{wk}$ ) dredging or construction work in a microtidal area. Resilience of ecosystems has been defined in at least 2 ways: (1) as the time required for a system to return to equilibrium after a disturbance (engineering resilience; e.g. Pimm 1984) or (2) as the amount of disturbance that a system can absorb before flipping to another state (ecological resilience; e.g. Holling 1973, Thrush et al. 2009 and references therein). By attempting to measure the approximate time it took for the deposition-treated system to become indistinguishable from the control system, we have adopted the first concept of the term resilience. We learnt from previous work, that MPB plays an important role in increasing the rate of recovery after various stressors (see references above); but these stressors did not involve light reduction. Therefore, we hypothesised that: (1) the reduction of light caused by sediment deposition, also being a physical obstacle for algae returning to the surface, will result in slower recovery of MPB and related sediment functions compared to stressors that do not affect the light climate and (2) because heterotrophic organisms do not-at least not initially and directly — become light limited, major functions driven by bacteria (remineralisation and denitrification) will recover faster than primary production. This would be the opposite order of recovery to that we noted after hypoxic events (Larson \& Sundbäck 2008, Engelsen et al. 2010), where 'dark functions' recovered more slowly than 'light functions'.

\section{MATERIALS AND METHODS}

\section{General approach}

Forty-eight intact sediment cores $(2$ treatments $\times$ 4 replicates $\times 6$ sampling occasions) were incubated in an outdoor flow-through system (see Larson \& Sundbäck 2008), where half of the sediment cores were exposed to a simulated deposition event (deposition cores) lasting for $1 \mathrm{wk}$ and half of them were left untreated (control cores). The response and recovery of the microphytobenthic community and 
sediment functions were followed during a period of $23 \mathrm{~d}$ by sampling on 6 occasions. Functional variables included day and night fluxes of $\mathrm{O}_{2}, \mathrm{NH}_{4}{ }^{+}, \mathrm{NO}_{3}{ }^{-}+$ $\mathrm{NO}_{2}{ }^{-}, \mathrm{PO}_{4}{ }^{3-}, \mathrm{Si}(\mathrm{OH})_{4}$, as well as denitrification. Structural variables included the chlorophyll a ( $\mathrm{chl} a)$ content and porosity of the sediment, and composition of microalgae.

\section{Sediment collection}

Sediment was collected from a boat with an Olausson box-corer $(30 \times 30 \mathrm{~cm})$ at a depth of $1.5 \mathrm{~m}$ in Munkeby Bay $\left(58^{\circ} 14^{\prime} \mathrm{N}, 11^{\circ} 32^{\prime} \mathrm{E}\right)$, next to a sound connecting the Gullmar and Koljö fjords on the west coast of Sweden. The area is microtidal, with a maximum tidal amplitude of $\sim 0.3 \mathrm{~m}$. When on deck, the sediment box-corer was carefully handled, not to disturb the sediment. A cylinder of black ABS plastics (co-polymer of acrylic nitrile, butadiene and styrene monomers) with a height and inner diameter of $25 \mathrm{~cm}$ was then lowered gently into the sediment until there was about $10 \mathrm{~cm}$ left to the cylinder top. A marine plywood plate was inserted from the side to function as a bottom for the cylinder. The sediment was silty, with a porosity of 0.84 . Prior to the treatment with sediment deposition, the cylinders were left for acclimatisation in the flow-through system for $1 \mathrm{wk}$.

\section{Experimental set-up}

The experiment was run for $23 \mathrm{~d}$ in summer (June) at the Lovén Centre for Marine Research, Kristineberg, near the Gullmar fjord. The system consisted of a greenhouse from which the side windows had been removed. This set-up allowed natural variations of light and temperature, but protected the system against precipitation. The cylinders were positioned randomly in a flow-through system and supplied with unfiltered surface water from the Gullmar fjord (salinity range: 26 to 32). The incoming water was directed to an elevated water cistern of 3001 and further by hydrostatic pressure via $10 \mathrm{~mm}$ tubing into 4 tubes $(300 \times 10 \mathrm{~cm})$, each with 12 outlets $(6 \mathrm{~mm})$, hanging over the sediment cylinders. These outlets led to inlets $(4 \mathrm{~mm}$ ) placed $5 \mathrm{~cm}$ below the upper rim of each cylinder, providing a flow of $\sim 10 \mathrm{l} \mathrm{h}^{-1}$. The overlying water depth was $\sim 10 \mathrm{~cm}$, providing a total water volume of $\sim 51$ cylinder $^{-1}$. Visible epifauna (a few Crangon sp.) were removed from the top of the sediment to avoid differences caused by their uneven distribution.

\section{Deposition of sediment}

We mimicked the deposition of dredged sediment by using sieved (1 $\mathrm{mm}$ mesh), fine-grained silt from a deeper suboxic sediment layer. The reason for using deeper lying sediment was to avoid addition of fauna and microalgae. The sediment was first slurred in water and bubbled with air under a flow-through system of surface seawater during $2 \mathrm{~d}$ for oxygenation and wash-out before use. Sediment was deposited during 7 consecutive days. At deposition, the water level in the cylinders was lowered, and 1.51 of seawater containing $75 \mathrm{ml}$ of the sediment-water slurry was added gently to each of the 24 deposition cylinders. This resulted in a deposition layer of $\sim 1.5 \mathrm{~mm} \mathrm{~d}^{-1}$ and a final layer of $10.5 \mathrm{~mm}$.

\section{Sampling}

Samples were taken from 4 control and 4 deposition cores on Days 1, 2, 4, 8, 15 and 23 after the initial 1 wk sediment deposition. We applied independent sampling, i.e. sampled cores were removed from the experiment. The first sampling was done within $4 \mathrm{~h}$ (Day 1) after the last deposition.

\section{Oxygen and nutrient fluxes}

Day-time and night-time fluxes between sediment and water were measured in 8 cylinders at each sampling (4 deposition cores, 4 control cores) by incubations under a transparent lid without water flow, but with stirring. For details of the incubation procedure, see Larson \& Sundbäck (2008). At the beginning of incubation, samples were taken for oxygen and nutrient concentrations. The time for incubation was set so that the oxygen concentration would not change more than $\sim 20 \%$, since interferences with nutrient fluxes can occur due to larger oxygen changes (Dalsgaard et al. 2000). The incubation time averaged just over an hour in light $(\sim 12: 00$ to $\sim 13: 00)$ and $\sim 2 \mathrm{~h}$ in the dark ( 00:00 to $\sim 02: 00)$. Oxygen concentrations were measured immediately after sampling using the Winkler technique (Strickland \& Parsons 1972). Nutrient samples were filtered (Sartorius ${ }^{\circledR} 0.45 \mu \mathrm{m}$ syringe filters) and immediately frozen $\left(-80^{\circ} \mathrm{C}\right)$. Ammonium $\left(\mathrm{NH}_{4}^{+}\right)$, nitrate + nitrite $\left(\mathrm{NO}_{3}{ }^{-}+\mathrm{NO}_{2}{ }^{-}\right)$, phosphate $\left(\mathrm{PO}_{4}{ }^{3-}\right)$ and silicate $\left(\mathrm{Si}(\mathrm{OH})_{4}\right)$ were analysed by wetchemistry methods with a TRAACS 2000 autoanalyser (Bran-Luebbe). 


\section{Denitrification}

Denitrification in light and dark was measured by the isotope pairing technique (Nielsen 1992). After nutrient-flux incubations, Plexiglas cylinders $(3.5 \mathrm{~cm}$ diameter, $25 \mathrm{~cm}$ height) were inserted into the sediment cylinders, initial samples for nitrogen concentrations were taken, and $1 \mathrm{ml}$ of $10 \mathrm{mM}^{15} \mathrm{NO}_{3}{ }^{-}(99.6$ at\%, Europe Scientific) was added to give a $\mathrm{NO}_{3}{ }^{-}$concentration corresponding to $\sim 30 \%$ of the oxygen concentration. After $0.5 \mathrm{~h}$ pre-incubation with label, new samples were taken to obtain the actual starting concentration of ${ }^{15} \mathrm{NO}_{3}{ }^{-}$. The time needed for diffusion of the label into the sediment was chosen on the basis of previous measurements in similar sediments, where the oxygenation depth had been checked by oxygen microelectrodes (Sundbäck et al. 2006). The cylinders were closed with tightly fitting Plexiglas plugs and incubated for $2 \mathrm{~h}$. To terminate the incubation, $0.5 \mathrm{ml}$ $\left(1 \mathrm{~g} \mathrm{ml}^{-1}\right)$ of zinc-chloride $\left(\mathrm{ZnCl}_{2}\right)$ was added and the sediment was slurred with the overlying water. Slurry samples were transferred into $12 \mathrm{ml}$ gas-tight vials, extra $\mathrm{ZnCl}_{2}(0.25 \mathrm{ml})$ was added, and the vials were tightly closed and stored in a refrigerator until analysis. The ${ }^{29} \mathrm{~N}_{2}$ and ${ }^{30} \mathrm{~N}_{2}$ produced were analysed with a gas chromatography and mass spectrometry (GCMS) system at the National Environmental Research Institute, Silkeborg, Denmark. Calculations of total denitrification $\left(D_{\text {tot }}\right)$ were carried out according to Dalsgaard et al. (2000).

\section{Porosity}

Samples for porosity were taken with cut-off $20 \mathrm{ml}$ syringes from the top $5 \mathrm{~mm}$ of the sediment. Porosity was determined by dividing the volume of water with the total sediment volume. A marked syringe at the sampling gave the total volume of sediment, and the volume of water was determined by subtracting the sediment dry weight, after $24 \mathrm{~h}$ in a $70^{\circ} \mathrm{C}$ oven, from the wet weight.

\section{Chlorophyll $a$ and benthic microalgae}

Samples for the sediment chl a content were taken with a cut-off $10 \mathrm{ml}$ syringe from the top $3 \mathrm{~mm}$ of the sediment (the approximate photic zone), pooling 4 subsamples from each replicate cylinder. Chl a was extracted in $3 \mathrm{ml}$ of $95 \%$ acetone, sonicated for $10 \mathrm{~min}$ in an ice-bath and stored in a refrigerator $\left(8^{\circ} \mathrm{C}\right)$ for $24 \mathrm{~h}$. The samples were centrifuged at
$3500 \mathrm{rpm}(g=340)$ for $10 \mathrm{~min}$, and the absorbance of the supernatant was analysed with a spectrophotometer (Shimadzu UV 2401-PC). Chl a was calculated according to Lorenzen (1967), with a correction for pheopigment content. Pieces of the covering microbial mats were peeled off, and the algal composition was qualitatively studied under a microscope, but no cell counts were made.

\section{Statistical analyses}

Two-way analysis of variance (ANOVA), with day and treatment as fixed factors was used to test for significant effects of sediment deposition and light and dark treatments. Homogeneity of variances was tested by Cochran's C-test, and, if found heterogeneous, data were transformed according to Underwood (1997). When there was significant interaction between factors, pair-wise comparisons of the means were made by the post-hoc Student-Newman-Keuls (SNK)-test. To check for leakage of nutrients from the deposited sediment, possible differences in the nutrient concentrations in the overlying water at the start of the flux measurements were tested by 1 -way ANOVA.

The sum of the response of functional variables referred to 'integrated community function'-was analysed by the program PERMANOVA, with treatment and day as fixed factors. This program does permutational multivariate analysis of variance (Anderson 2001, McArdle \& Anderson 2001) on the basis of any distance measure, using permutation procedures to obtain $\mathrm{p}$-values for the tests (including interactions), for any balanced multifactorial ANOVA design (up to 9 factors). Our data set included 6 functions (denitrification, oxygen and nutrient fluxes) and was tested separately for light and dark. Raw data were not transformed but standardised. To find when the deposition treatment was inseparable from the controls, pair-wise a posteriori comparisons were done with the factor treatment under each level of the factor day. Permutational multivariate dispersion analysis (PERMDISP) was run to look for differences in within-group dispersion based on the distance of replicates from their group centroid. Principal coordinate analysis ( $\mathrm{PCO}$, also known as metric multidimensional scaling) was calculated and plotted. The programs PERMANOVA V1.6, PERMDISP and PCO3 were used (M. J. Anderson, Department of Statistics, University of Auckland, New Zealand; www.stat.auckland.ac.nz/ mja/ Programs.htm). 


\section{RESULTS}

All variables, except net primary production (NPP) and nitrate flux, were affected by the sediment deposition. The 2 state variables, chl $a$ and porosity, were consistently affected, while the timing and extent of the functional variables varied (Table 1, Figs. 1 to 4 ). Immediately after the deposition was stopped, sediment-water nutrient fluxes generally turned from sediment uptake to release (Fig. 3). At the end of the experiment (Day 23), 3 variables remained significantly affected, i.e. porosity (increase), chl a (decrease) and phosphate flux in the dark (increase) (Table 1).

\section{Porosity and the microbenthic community}

Sediment deposition increased the porosity of the top $5 \mathrm{~mm}$ of the sediment significantly, remaining $\sim 10 \%$ higher throughout the experiment; no decreasing trend was seen through sediment compaction (Table 1, Fig. 1a). Chl a content in the uppermost $3 \mathrm{~mm}$ had decreased on Day 1 by $75 \%$ and remained significantly lower throughout the experiment (Fig. 1b). A significant increasing linear trend $\left(\mathrm{R}^{2}=\right.$

Table 1. The effect of sediment deposition tested by 2 -factor ANOVA. Functional variables are shown separately for light and dark. T: significant main-factor effect of sediment deposition (treatment); $\mathrm{D} \times \mathrm{T}$ : significant interaction between time (day) and sediment deposition; SNK: StudentNewman-Keuls test; ns: not significant; NPP: net primary production; CR: community respiration

\begin{tabular}{|lccc|}
\hline Variable & $\begin{array}{c}\text { Significant } \\
\text { factor(s) }\end{array}$ & $\mathrm{p}$ & $\begin{array}{c}\text { Significant on } \\
\text { days (SNK) }\end{array}$ \\
\hline Porosity & $\mathrm{T}$ & 0.0001 & \\
Chlorophyll a & $\mathrm{T}$ & 0.0001 & \\
Light & & & \\
Oxygen (NPP) & & $\mathrm{ns}$ & \\
Chl a-normalised & $\mathrm{D} \times \mathrm{T}$ & 0.011 & 2,4 \\
$\quad$ production & & & \\
Ammonium & $\mathrm{D} \times \mathrm{T}$ & 0.0001 & $1,2,4$ \\
Nitrate & & $\mathrm{ns}$ & \\
Phosphate & $\mathrm{D} \times \mathrm{T}$ & 0.003 & $1,4,8$ \\
Silicate & $\mathrm{D} \times \mathrm{T}$ & 0.001 & $1,4,8$ \\
Denitrification & $\mathrm{D} \times \mathrm{T}$ & 0.022 & 15 \\
Dark & & & \\
Oxygen (CR) & $\mathrm{T}$ & 0.006 & \\
Ammonium & $\mathrm{D} \times \mathrm{T}$ & 0.001 & 1,4 \\
Nitrate & & $\mathrm{ns}$ & \\
Phosphate & $\mathrm{D} \times \mathrm{T}$ & 0.0001 & $1,2,4,23$ \\
Silicate & $\mathrm{D} \times \mathrm{T}$ & 0.0001 & 1 \\
Denitrification & $\mathrm{D} \times \mathrm{T}$ & 0.001 & 1,4 \\
\hline
\end{tabular}
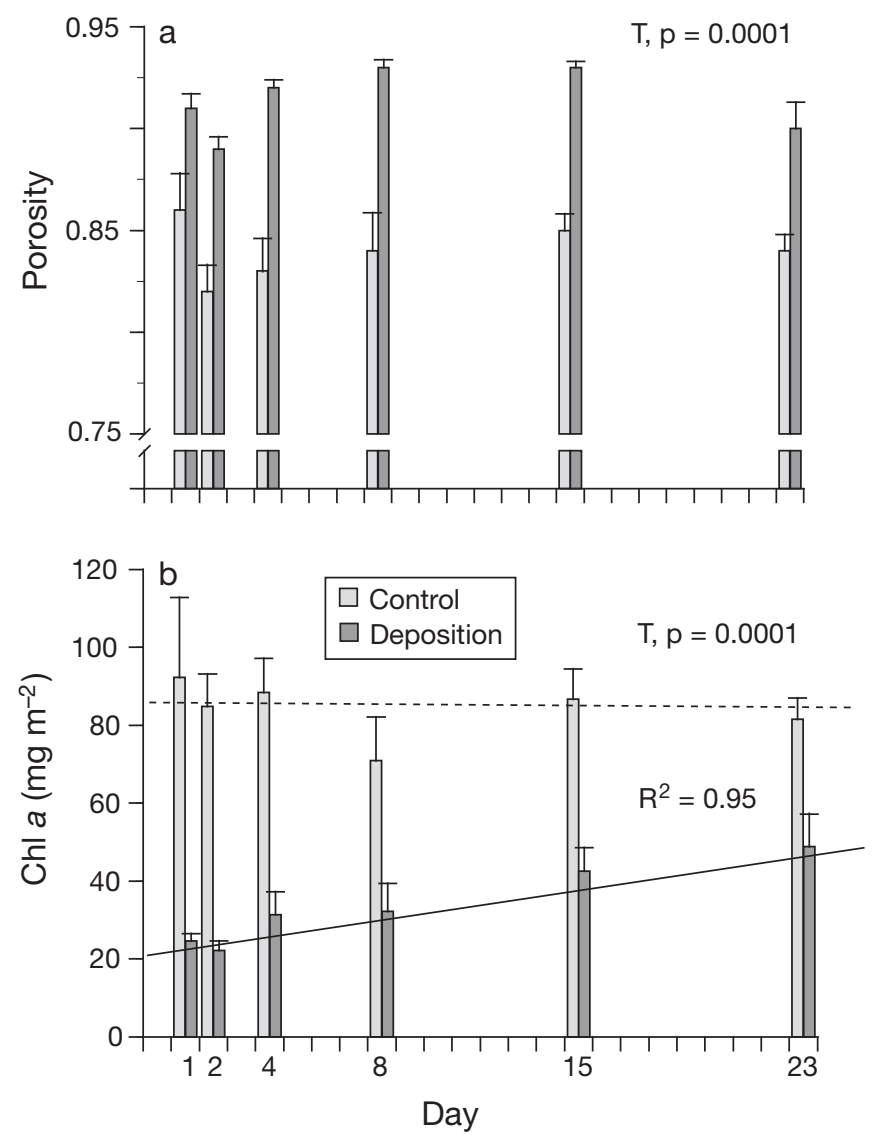

Fig. 1. (a) Porosity and (b) chlorophyll a (chl a) contents in control and deposition cores. Means $+\mathrm{SE}, \mathrm{n}=4$. $\mathrm{T}$ : significant main factor effect (treatment). For chl $a$, the linear trend line for prediction of the point of algal biomass recovery is shown. The horizontal dashed line shows the mean concentration of chl $a$ in the control cores

0.95) in the deposition cores indicated that chl a concentration would converge with that of the controls around Day 52, i.e. $7.5 \mathrm{wk}$ after the sedimentation stopped (Fig. 1b).

Newly formed cohesive diatom mats were clearly visible in the deposition cores from Day 8 onwards. During days with high primary production, oxygen bubbles were trapped in the algal mat, producing flakes that floated away. This flaking was more frequent in the deposition cores than in the control cores. Semi-quantitative microscope studies suggested that the deposition affected the composition of the benthic algal mat. Large motile, sigmoid diatoms, such as Pleurosigma sp. and Gyrosigma sp. $(>500 \mu \mathrm{m})$ dominated the newly established algal mats of the deposition cores, while smaller pennate diatoms remained common in the control cores. Filamentous cyanobacteria (Oscillatoria sp.) were only found in the control cores. 

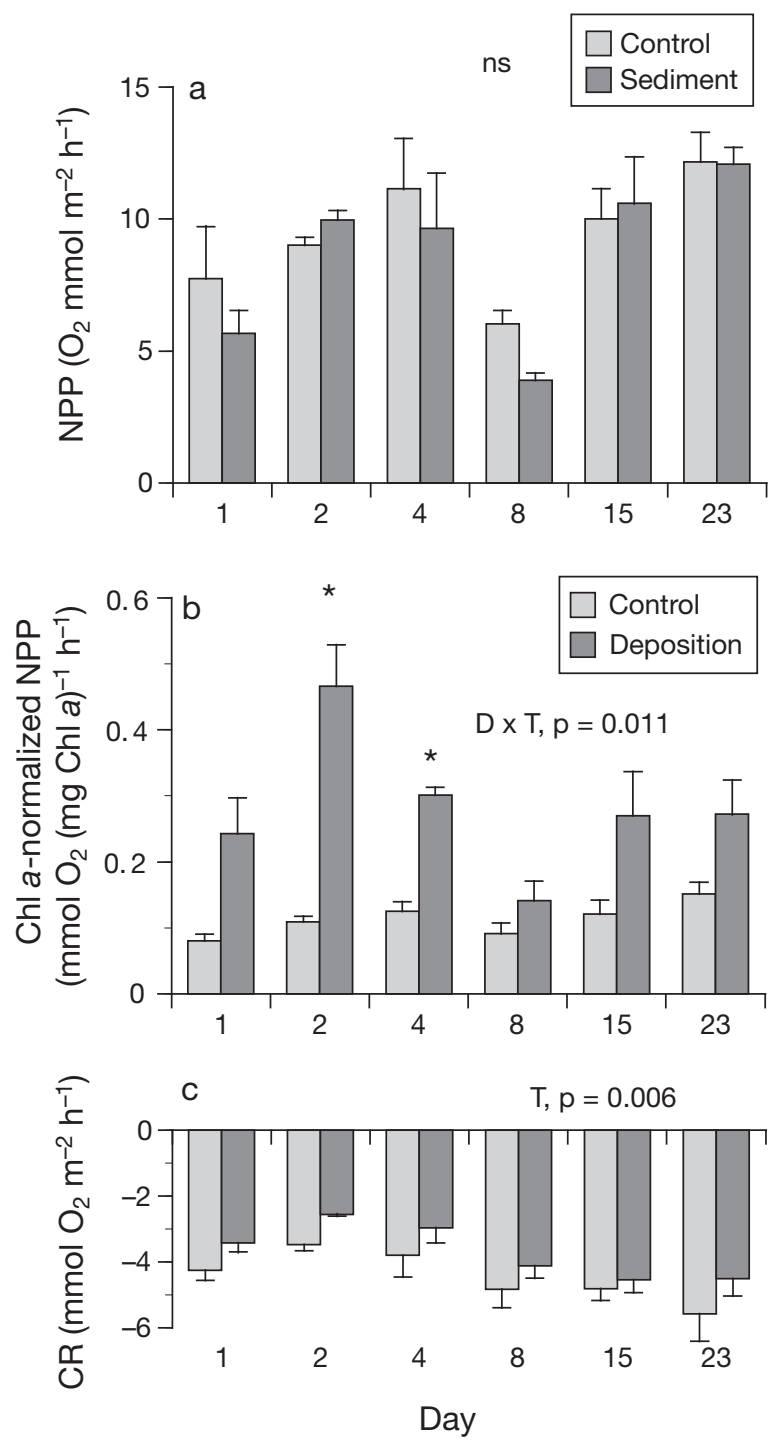

Fig. 2. (a) Oxygen production in light (net primary production, NPP; no significant differences, ns), (b) chl a-normalised NPP and (c) oxygen consumption in the dark (community respiration, CR) in control and deposition cores. Means + SE, $\mathrm{n}=4 .{ }^{*}$ : significant deposition effect according to the post hoc test (Student-Newman-Keuls)

\section{Functional variables}

\section{General pattern and nutrient concentrations}

Only dark fluxes of oxygen were consistently affected by deposition, while the effect on other rates depended on time (Figs. 2 to 4 ). The sediment system remained net autotrophic (production/respiration $[P / R]>1)$ throughout the experiment, with nutrient fluxes typically directed towards the sediment, also in the dark (Fig. 3). In the control cores, the uptake in

light was significantly higher than in the dark, except for ammonium (2-way ANOVA, D $\times \mathrm{T}, \mathrm{p}<0.05)$, reflecting the influence of microalgal activity on flux rates. The release of nutrients immediately after deposition (Day 1) gradually decreased and mostly switched to uptake (Fig. 3). There was a tendency (not statistically proven) that the initial quantitative effect of deposition on nutrient fluxes was larger in light than in the dark, but with the opposite situation for denitrification.

Generally, nutrient concentrations in the surface water (i.e. initial flux concentrations) were low (ammonium $<1.5 \mu \mathrm{M}$, nitrate + nitrite $<2 \mu \mathrm{M}$ except for Day 15 [4 to $5 \mu \mathrm{M}$ ], phosphate $<0.2 \mu \mathrm{M}$, silicate 0.3 to $3 \mu \mathrm{M}$ ), with no significant differences between treatments (1-way ANOVA, p > 0.1), suggesting no or little direct leakage from the deposited sediment.

\section{Light fluxes}

Although NPP in the deposition cores appeared lower on Days 1 and 8 (Fig. 2a), there was no overall significant deposition effect. The combination of strongly decreased chl a content and unaffected oxygen production resulted in a significant increase of chl a-normalised NPP (Fig. 2b, Table 1). This somewhat unexpected result may have several explanations (see 'Discussion').

Ammonium flux was affected significantly by deposition (Fig. 3a), whereas nitrate flux was not (Fig. 3c). For both phosphate and silicate, the deposition induced initially a large efflux (3-fold the uptake in control cores) (Fig. 3e,g). Although both fluxes decreased gradually, the deposition effect was still significant on Day 8 (Fig. 3e,g). The effect of sediment deposition was less obvious for denitrification, which was affected only once in light (Day 15) (Table 1, Fig. 4).

\section{Dark fluxes}

The only functional variable that showed a significant overall (main factor) effect of sediment deposition was community respiration $\left(\mathrm{CR}_{i}\right.$ oxygen uptake in the dark), although the effect was quantitatively rather low (Table 1, Fig. 2c). As in the light, there was on Day 1 a significant release of $\mathrm{NH}_{4}{ }^{+}$, which then turned into uptake ((Table 1, Fig. 3b). No significant effects at all were found for nitrate in the dark (Fig. 3d). Phosphate was released from the deposition cylinders in the dark, while it was taken up in the 


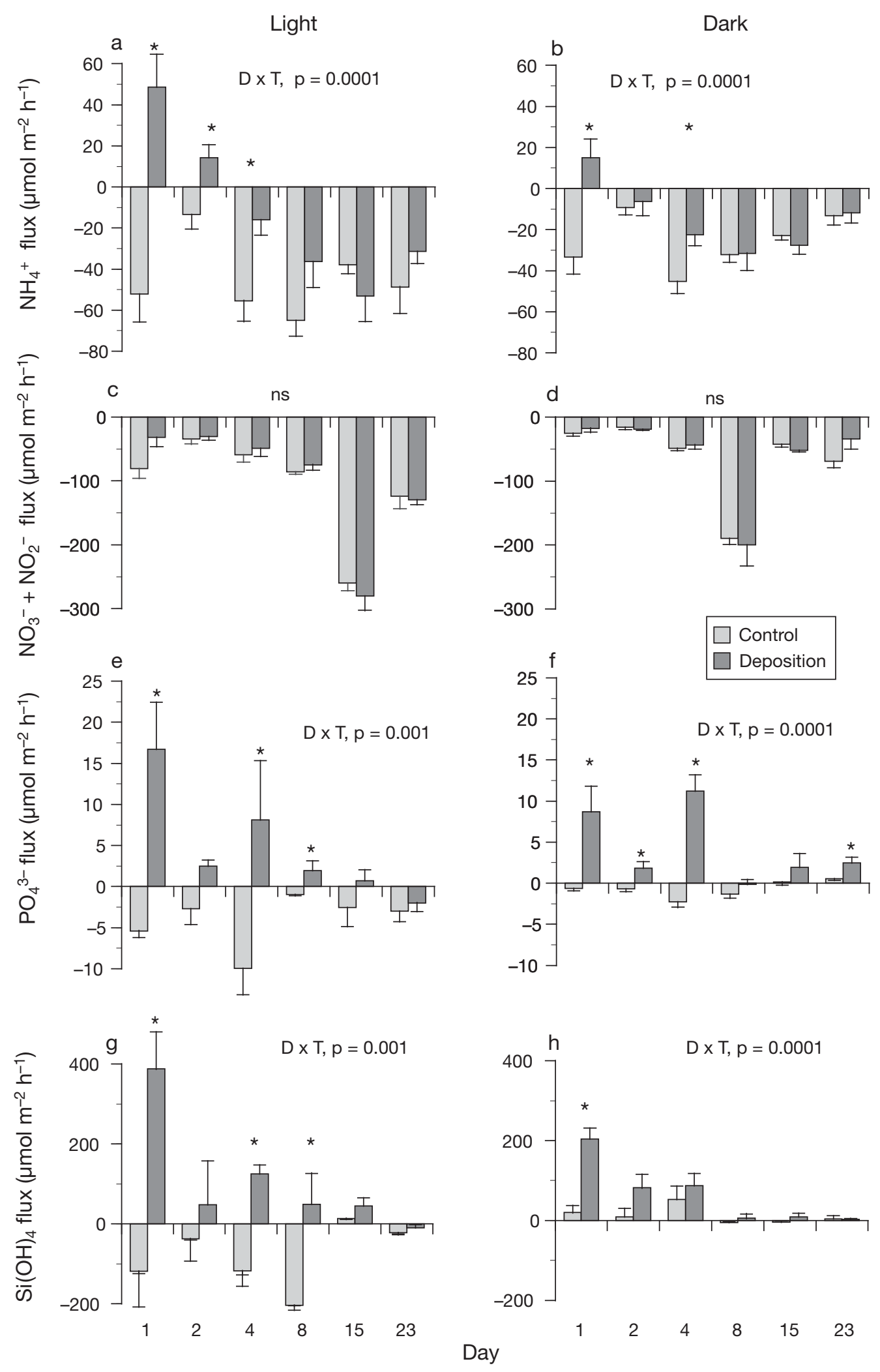

Fig. 3. Sediment-water fluxes of: $(\mathrm{a}, \mathrm{b})$ ammonium, $(\mathrm{c}, \mathrm{d})$ nitrate + nitrite, $(\mathrm{e}, \mathrm{f})$ phosphate and $(g, \mathrm{~h})$ silica in light and dark in control and deposition cores. Means $+\mathrm{SE}, \mathrm{n}=4$. T: significant main-factor effect of sediment deposition (treatment); $\times$ T: significant interaction between time (day) and sediment deposition; ns: not significant; ${ }^{*}$ : significant deposition effect according to the post hoc test (Student-Newman-Keuls) 

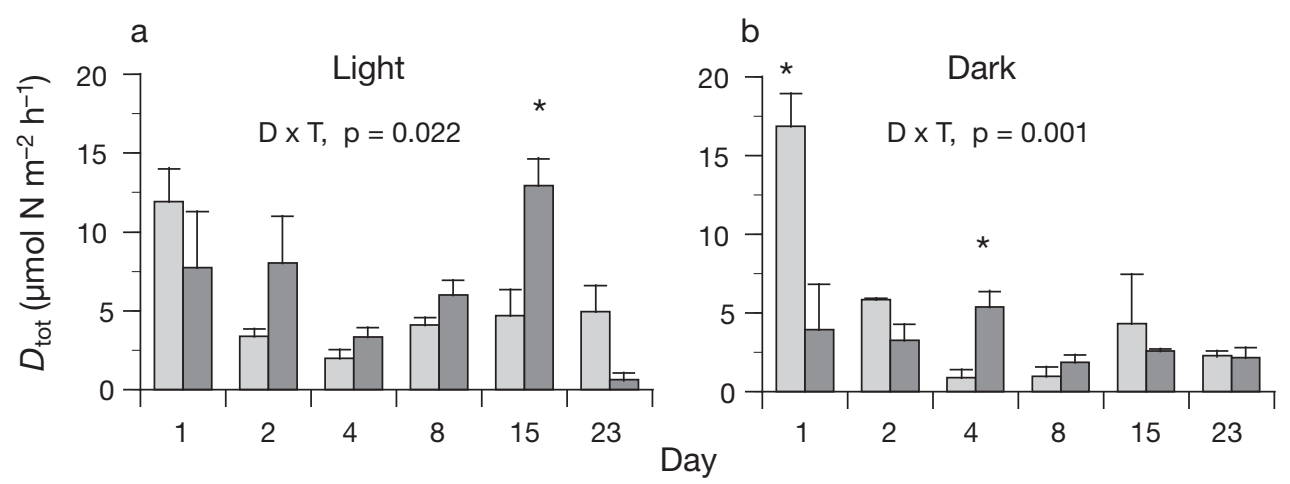

Fig. 4. Denitrification $\left(D_{\text {tot }}\right)$ in (a) light and (b) dark in control (light grey bars) and deposition cores (dark grey bars). Means + SE, $\mathrm{n}=4$. $^{*}$ : significant deposition effect according to the post hoc test (StudentNewman-Keuls)

controls (Table 1, Fig. 3f). For silicate, release was significantly higher from the deposition-treated cores only on Day 1 (Table 1, Fig. 3h). In contrast to light, there was a large initial negative effect on denitrification in the dark, which later (Day 4) turned into a stimulating effect (Fig. 4).

\section{Resilience of 'integrated community function'}

Multivariate analysis (PERMANOVA) was used to assess the resilience (interpreted as the rate of recovery) of the 'sum' of variables, which we call 'integrated community function'. Six variables were used in the analyses: fluxes of oxygen, ammonium, nitrate + nitrite, phosphate and silicate, as well as denitrification, which were analysed separately for light and dark conditions (Table 2, Fig. 5).

Initially, the deposition affected the integrated function both in the light and the dark, as shown by the significant differences in the pair-wise comparisons following PERMANOVA (Table 2, Fig. 5). The recovery rate was, however, different in light and dark. In the dark, recovery was already apparent by Day 2, while in the light recovery was seen only after 2 wk (Day 15) (Table 2, Fig. 5), with significant differences between treatments on Days 1, 4 and 8 ( $p<0.05$ ). On Days 1 and 4, the groups were clearly separated and showed about the same level of within-group dispersion. On Day 8, however, the deposition replicates showed significantly greater dispersion (PERMDISP; Table 2). For Day 23, the sig- nificant difference in dispersion was opposite, with deposition replicates more tightly grouped than the controls; however, they remained around the same spot and were not separated by PERMANOVA. The observed significant effect on denitrification on Day 15 in light (Fig. 4) was not strong enough to generate a difference in the integrated function.

Although PERMANOVA showed only an initial deposition effect on the integrated function in the dark, PERMDISP revealed a significant treatment effect on the dispersion of the replicates $(p<0.05$ ) (Table 2, Fig. 5). The deposition replicates had a

Table 2. Results from the permutational multivariate ANOVA (PERMANOVA) and the permutational multivariate dispersion analysis (PERMDISP) on the effects of sediment deposition on 'integrated community function'. Shown are also a posteriori pair-wise comparisons of treatment $(\mathrm{T})$ under each level of day (D). The 6 variables included in the analyses were denitrification, and fluxes of oxygen, ammonium, nitrate + nitrite, phosphate and silicate measured in light and dark. Significances of $p<0.05$ are shown in bold, $p>0.05$ in regular font

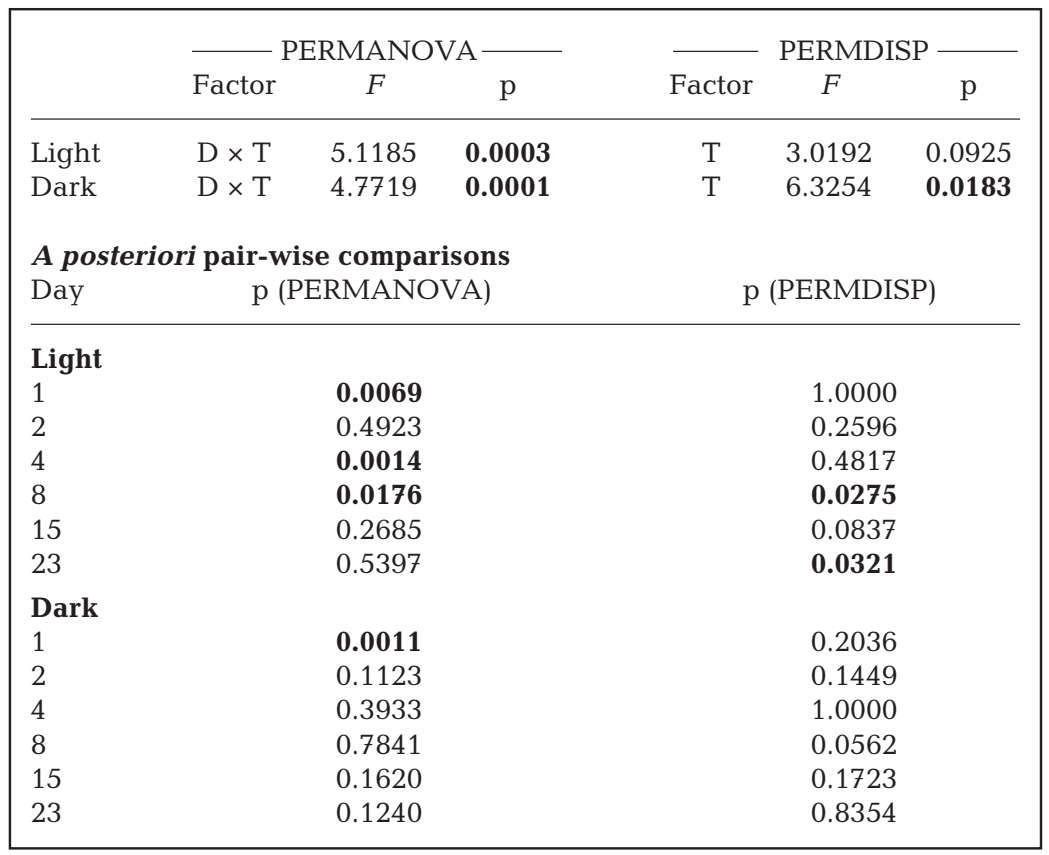



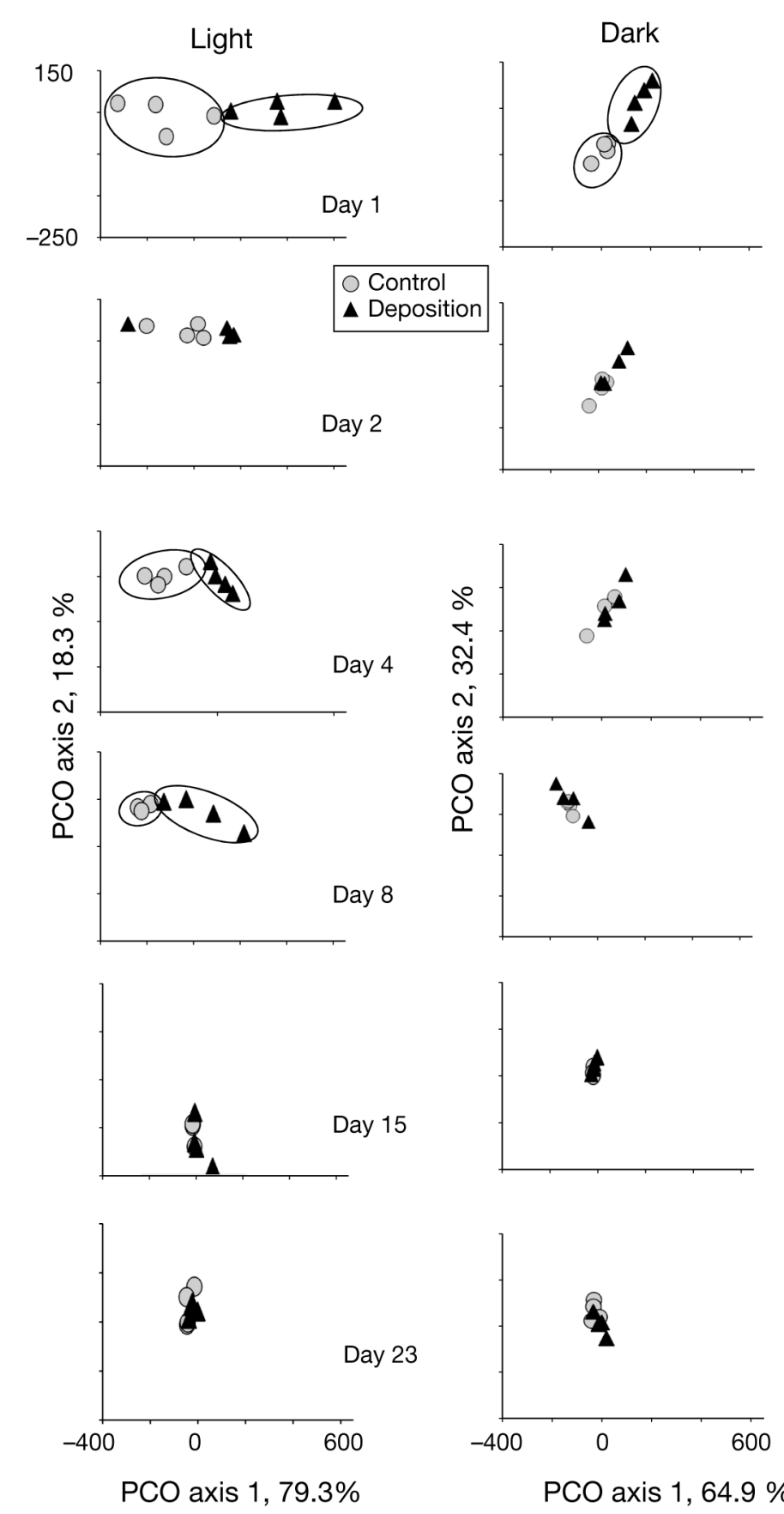

Fig. 5. Response and recovery of the integrated community function after sediment deposition analysed by PERMANOVA and plotted as principal coordinates (PCO). Coordinates were calculated from a matrix including 6 variables (denitrification and fluxes of oxygen, ammonium, nitrate + nitrite, phosphate and silicate), with separate analyses for light and dark conditions. The treatments are significantly separated on Day 1 in both light and dark. After Day 1, there are no differences in the dark, while in the light the treatments are also significantly separated on Days 4 and 8. On Day 8, in light, there is also a significant difference in within-group dispersion. For PERMANOVA and PERMDISP statistics, see Table 2 slightly higher dispersion over the experimental period. From Day 2, the 2 replicate groups gradually became more similar. On the level of individual variables, some differences remained (cf. Figs. 3 \& 4), but did not coincide strongly enough to separate the treatment groups.

Since only 2 non-functional variables (porosity and chl a) were measured, they were not analysed by PERMANOVA. In contrast to the integrated function, chl a content and porosity did not recover over the course of the experiment (Fig. 1).

\section{DISCUSSION}

Our main results can be summarised as follows. (1) Both structure and function of the microbenthic community were affected by the deposition event. (2) MPB biomass (chl a) was initially strongly reduced, and, despite a linear increase, full recovery could not be expected until after $7 \mathrm{wk}$. The composition remained in its altered state. (3) Higher porosity in the deposition cores increased the risk of flaking of the algal mats. (4) Functions directly related to photosynthetically active algae (NPP and nutrient fluxes in light) recovered faster than algal biomass. (5) Still, fluxes in light initially appeared to be more strongly affected than in the dark, in contrast to the pattern observed in previous experiments dealing with stressors that do not directly affect light conditions. (6) Integrated community function recovered faster in the dark.

The results supported our first hypothesis regarding a relatively slow recovery of MPB biomass. Although our second hypothesis regarding a more rapid recovery of 'dark functions' was not unambiguously supported by the response of individual functions, the observed faster recovery of the integrated community function in the dark did. While functions in the light remained affected for $2 \mathrm{wk}$, functions in the dark appeared to have already recovered after $1 \mathrm{~d}$.

\section{Methodological aspects}

Our decision to use intact natural sediment entailed a deliberate trade-off between retaining the original complexity of the system and obtaining more clear-cut results from simplified systems due to better reproducibility. To increase the relevance of the measured recovery after simulated shortterm dredging or construction work, the deposition 
event lasted for $1 \mathrm{wk}$. Since the only connection with the surrounding marine environment was the incoming unfiltered seawater, no horizontal immigration from nearby sediment was possible. In this sense, our sediment deposition-despite the limited area of the experimental cylinders $\left(490 \mathrm{~cm}^{2}\right)$ - should have fairly well simulated a scenario with a larger area covered by deposited sediment. Hence, at least the initial responses to deposition were due to indigenous organisms, although colonisation by, e.g., bacteria from inflowing water may have been very fast.

One limitation of our set-up could have been that we, because of a water column of only $10 \mathrm{~cm}$, underestimated the effect of increased turbidity; in a higher water column, fine particles may stay suspended longer, reducing light. Despite some limitations of our set-up, our results should still be of acceptable ecological relevance regarding the simulated scenario.

\section{Sensitivity and resilience of microphytobenthos at sediment deposition}

We hypothesised that the light exclusion caused by sediment deposition, also being a physical obstacle for algae returning to the surface, would result in slower recovery of MPB and related sediment functions when compared with effects of stressors that do not influence the light climate (e.g. hypoxia, toxicants). This proved to be true for microalgal biomass (chl a), which decreased by $75 \%$ and was estimated to recover fully only after $7 \mathrm{wk}$. Neither hypoxia, nor toxicant exposure were found to have such a strong and long-standing negative effect on sediment chl a (Piehler et al. 2003, Alsterberg et al. 2007, Larson et al. 2007, Larson \& Sundbäck 2008, Petersen et al. 2009, Engelsen et al. 2010).

\section{Importance of vertical migration}

Benthic diatoms are generally considered to withstand harsh conditions and various disturbances, such as resuspension, darkness, hypoxia, $\mathrm{H}_{2} \mathrm{~S}$ and even toxicants (Admiraal 1984, Sundbäck et al. 1990, Underwood \& Paterson 1993, Larson et al. 2007, Larson \& Sundbäck 2008). However, being gradually covered by a layer of $1 \mathrm{~cm}$ of fine sediment was obviously a severe disturbance for the MPB. The linear increase of chl a that we found implies that the reoccurrence of algae on the sediment surface was mainly driven by vertical upward migration (cf. Wulff et al. 1997), although growth may also have played a role.

We expected that the recovery per millimetre deposition in our original silty sediment would be faster compared to that in sandy sediment, where epipsammic, non-motile, or slowly moving microalgal species dominate. Wulff et al. (1997) found a re-colonisation rate of $8 \mathrm{~d}$ for a $2.5 \mathrm{~mm}$ layer of deposited fine sediment, so we expected a faster rate (i.e. $<34 \mathrm{~d}$ per $10.5 \mathrm{~mm}$ ), because MPB species of fine-grain sediments can be assumed to be better adapted to deposition because of their capability to move faster (e.g. Hay et al. 1993, Jönsson et al. 1994). The observation that large motile diatoms (>500 $\mu \mathrm{m})$ dominated the newly formed MPB mats in the deposition cores supports the assumption that the larger diatoms moved faster and also agrees with similar findings by Wulff et al. (1997). However, if our sigmoid diatoms (Gyrosigma sp. and Pleurosigma sp.) moved as fast as Gyrosigma spenceri on a tidal flat (0.19 $\mathrm{\mu m} \mathrm{s}^{-1}$; Hay et al. 1993), it would have taken only $\sim 2.5 \mathrm{~h}$ for them to migrate through a daily $1.5 \mathrm{~mm}$ deposition layer. As this did not happen, the upward migration in our non-tidal sediments may have been controlled by other factors, such as the light threshold of the phototactic response, which is known to vary between species (Paterson 1986).

Diatoms have been found to increase their dominance over cyanobacteria at the surface of sediments subjected to deposition (Parodi \& de Cao 2002). We found filamentous cyanobacteria (mainly Oscillatoria sp.) in the controls, but not in the deposition cores. Oscillatoria sp. is motile, but perhaps its long chains may delay its optimal positioning for vertical migration.

\section{Rate of recovery}

The predicted time of $52 \mathrm{~d}$ to the point of recovery of the MPB biomass represents a long recovery time in relationship to MPB. In previous stressor experiments, chl a recovered in $<10 \mathrm{~d}$ (Alsterberg et al. 2007), showed no negative response at all (Larson \& Sundbäck 2008), or even increased later because of indirect effects (Larson et al. 2007, Larson \& Sundbäck 2008, Petersen et al. 2009, Sundbäck et al. 2010). So why was NPP not negatively affected as was biomass, resulting in higher chl a-normalised oxygen production? Rodil et al. (2011) found the opposite situation for sandy sediment (no effect on chl $a$, lower primary production) after deposition of terrigenous sediment. They explained the results by 
different levels of nutrient limitation. Silty sediments in coastal areas generally contain high concentrations of nitrogen and phosphorus, and therefore nutrient limitation is less likely in such sediments (Fisher et al. 1982, Sundbäck et al. 2003, Engelsen et al. 2008). We deposited washed sediment, but in situ considerable organic enrichment can be expected in association with the outwash from dredging (Newell et al. 1999), and did not measure dissolved organic nutrients in our experiment. Thus, we can only speculate possible explanations for the higher chl anormalised production with deposition. Reasons could include the different physiologies and behaviours of dominating motile species, or the release from resource competition (light and nutrients) within the less dense microbial mats when compared with controls. The most probable explanation may be flaking, leading to underestimation of the chl a content in sediment, while flakes in the water column contribute to benthic oxygen production.

\section{Flaking}

The deposition of fine-grained sediment increases porosity, resulting in a more flocculent surface material and subsequent flaking. Although keeping sediment in experimental containers in itself may increase flaking (Alsterberg et al. 2011), flaking was more frequent in the deposition cores. In conjunction with restored photosynthetic oxygen production, paralleled by increased production of extracellular polymeric substances (EPS), probably due to increased diatom motility, the risk of mat loss increased because of increased buoyancy. The more fluid, lessstable deposited sediment below the microbial mat did not counteract the traction force from the mat buoyancy acting upon the connection between the mat and the underlying sediment. In situ, this may lead to a loss of the microbial mat over large areas (for discussion on flaking, see Sutherland et al. 1998), delaying benthic mat recovery. In tidal areas, the sediment is regularly compacted due to de-watering during low-tide emersion (Perkins et al. 2003), but this does not happen in non-tidal or sub-tidal sediments, where the risk of flaking becomes greater. The recovery of initial sediment characteristics after deposition can, however, also take long in intertidal areas (Cummings et al. 2003). The most important factors influencing the recovery of surface sediment characteristics are probably local hydrodynamics (Dernie et al. 2003) in combination with the topography of the area and surroundings.

\section{Recovery of functions}

While the recovery of the MPB biomass appeared slow, the recovery of functional variables was fast. Still, the influence of the affected MPB on the functions was evident. In the dark, the deposition effect appeared only on the first day after final sediment deposition, while, in the light, the effect remained at least until Day 8 (Fig. 5). From Day 15 onwards, when the chl a content in the deposition cores increased to $50 \%$ of that in the controls, no more effects were seen in 'light functions'. Ammonium, silicate and especially phosphate fluxes were clearly affected by deposition, with either lower uptake (ammonium) or higher release $(\mathrm{P}, \mathrm{Si})$. The changed flux pattern was probably not only a result of initially decreased uptake by MPB, but also of increased permeability of the deposited material because of the initial lack of a cohesive microbial mat. In permeable sediments, advective flow enhances fluxes, driving pore water out of the sediment (e.g. Forster et al. 1996). The reason for no or only a minor effect of deposition on nitrate and denitrification could be due to the rapid restoration of the oxygen gradient in the sediment.

Our second hypothesis was that functions mainly driven by bacteria (e.g. remineralisation and denitrification) will recover faster than functions directly related to light-dependent primary producers. This is the opposite of our results from previous stressor experiments, where MPB played a key role in community resilience (e.g. Sundbäck et al. 2007, Larson \& Sundbäck 2008, Engelsen et al. 2010). In the present deposition experiment, the expected contrary results were not as obvious when looking at the response of individual functional variables, although $\mathrm{PO}_{4}{ }^{3-}$ and $\mathrm{Si}(\mathrm{OH})_{4}$ fluxes particularly supported our hypothesis. The multivariate analyses, however, supported our hypothesis of a faster recovery in the dark than in light (Fig. 5). The multivariate analysis depicting the 'integrated community function' thus appeared to be more powerful for studying recovery than were individual variables.

\section{Scales}

Both temporal and spatial scales are crucial when experimenting with recovery (e.g. Norkko et al. 2006). As we wanted to study microbenthos and sediment-nutrient fluxes, we chose to do our experiment in a system on land. Most field experiments on recovery have been on macrofauna, and recovery times of at least 100 to $200 \mathrm{~d}$ up to several years after physical 
disturbance events have been found (Boyd et al. 2003, Lundquist et al. 2004, Norkko et al. 2006, Thrush et al. 2009, Borja et al. 2010 and references therein). When compared with macrofauna, the recovery time of MPB in our experiment was still relatively short. Since there is a vast difference in both generation time and turnover between macrobenthos and MPB, such a difference is intuitively expected, and has also been predicted through modelling of resilience (DeAngelis 1980, DeAngelis et al. 1989). To understand the relation between macroand microbial components and processes for community and system resilience, it is important to simultaneously consider different size groups of organisms, but such studies are still rare (Stocks \& Grassle 2001, Montserrat et al. 2008, Rodil et al. 2011). Interestingly, Rossi et al. (2009), who studied microbial carbon flow through MPB and bacteria together with macrofaunal recovery, concluded that (macroscopic) species assemblages and ecosystem function recovered relatively independently in a tidal benthic system. However, they did not study the structure of microscopic assemblages. We observed a lasting change in the microbial community (MPB), despite the restored community function (primary production), pointing at an inherent redundancy of the microphytobenthic community. Besides scale, local hydrodynamic conditions and adjacent areas influence the extent of effects and the recovery from sedimentation (Cruz-Motta \& Collins 2004), but these aspects are outside the scope of our study.

\section{Conclusions}

Sediment deposition can be a severe disturbance to MPB, which is often the most important primaryproducing component of shallow-water sediments void of macroscopic vegetation. Parts of the MPB may manage to rapidly return to the surface, perform photosynthesis and grow, thereby restoring the oxygenation of the sediment surface. However, not only does the sediment deposition constitute a physical cover on the microalgal mat, but it also provides a less stable, more porous substrate for the newly established microbial mat. This change of substrate type increases the risk of flaking and loss of mat, especially in areas with constantly inundated sediments, delaying the recovery of crucial benthic ecosystem functions. Deposition of a permeable layer of fine sediments can also increase benthic release of nutrients, enhancing eutrophication by internal nutrient loading. The function of the lower trophic levels - microbenthos - should therefore be taken into account when permitting activities that cause increased sedimentation. Even a thin deposited layer can limit the food supply for grazers, deposit feeders and filter feeders, also ultimately decreasing the food supply for fishes that use shallow-water sediments as nurseries.

Acknowledgements. Funding was received from the Swedish Environmental Protection Agency, the Research Council for Environment, Agricultural Sciences and Special Planning (FORMAS), the Royal Society of Sciences and Arts in Gothenburg (KVVS), the Marine Research Centre of Gothenburg University (GMF), the foundations of Birgit and Birger Wåhlström and Kapten Karl Stenholm. We are grateful to T. Olsson for the skilled work he performed as fieldassistant during sediment collection, experimental set-up and sampling. We thank the crew of RV 'Oscar von Sydow' for excellent help with the joyful collection of sediment. We also thank C. Gren and G. Gunnarsson for help in the workshop at Kristineberg Marine Station. We thank 4 anonymous reviewers for constructive criticism on an earlier version.

\section{LITERATURE CITED}

Admiraal W (1984) The ecology of estuarine sedimentinhabiting diatoms. In: Round FE, Chapman DJ (eds) Progress in phycological research, Vol 3. Biopress, Bristol, p 269-322

Alsterberg C, Sundbäck K, Larson F (2007) Direct and indirect effects of an antifouling biocide on benthic microalgae and meiofauna. J Exp Mar Biol Ecol 351:56-72

Alsterberg C, Hulth S, Sundbäck K (2011) Response of a shallow-water sediment system to warming. Limnol Oceanogr 56:2147-2160

Anderson MJ (2001) A new method for non-parametric multivariate analysis of variance. Austral Ecol 26:32-46

> Borja Á, Dauer DM, Elliot M, Simenstad CA (2010) Mediumand long-term recovery of estuarine and coastal ecosystems: patterns, rates and restoration effectiveness. Estuaries Coasts 33:1249-1260

Boyd SE, Limpenny DS, Rees HL, Cooper KM, Campbell S (2003) Preliminary observations of dredging intensity on the re-colonization of dredged sediment off the southeast coast of England (Area 222). Estuar Coast Shelf Sci 57: 209-223

> Costanza R, d'Arge R, de Groot R, Farber S and others (1997) The value of the world's ecosystem services and natural capital. Nature 387:253-260

> Cruz-Motta JJ, Collins J (2004) Impacts of dredged material disposal on a tropical soft-bottom benthic assemblage. Mar Pollut Bull 48:270-280

Cummings V, Thrush S, Hewitt J, Norkko A, Pickmere S (2003) Terrestrial deposits on intertidal sandflats: sediment characteristics as indicators of habitat suitability for recolonising macrofauna. Mar Ecol Prog Ser 253:39-54

Dalsgaard T, Nielsen LP, Brotas V, Viaroli P and others (2000) Protocol handbook for NICE — nitrogen cycling in estuaries. Department of Lake and Estuarine Ecology, Ministry of Environment and Energy, National Environmental Research Institute, Silkeborg

> DeAngelis DL (1980) Energy flow, nutrient cycling, and 
ecosystem resilience. Ecology 61:764-771

DeAngelis DL, Mulholland PJ, Palumbo AV, Steinman AD, Huston MA, Elwood JW (1989) Nutrient dynamics and food-web stability. Annu Rev Ecol Syst 20:71-95

> Dernie KM, Kaiser MJ, Warwick RM (2003) Recovery rates of benthic communities following physical disturbance. J Anim Ecol 72:1043-1056

- Engelsen A, Hulth S, Pihl L, Sundbäck K (2008) Benthic trophic status and nutrient fluxes in shallow-water sediments. Estuar Coast Shelf Sci 78:783-795

Engelsen A, Sundbäck K, Hulth S (2010) Links between bottom-water anoxia, the polychate Nereis diversicolor and the growth of green-algal mats. Estuaries Coasts 33: 1365-1376

> Fisher TR, Carlson PR, Barker RT (1982) Sediment nutrient regeneration in three North Carolina estuaries. Estuar Coast Shelf Sci 14:101-116

> Forster S, Huettel M, Ziebis W (1996) Impact of boundary layer flow velocity on oxygen utilisation in coastal sediments. Mar Ecol Prog Ser 143:173-185

> Haese RR, Pronk GJ (2011) Intra-annual variability in primary producer groups and nitrogen dynamics in an intermittently closed estuary exposed to Mediterranean climate. Estuaries Coasts 34:557-568

> Hay SI, Maitland TC, Paterson DM (1993) The speed of diatom migration through natural and artificial substrata. Diatom Res 8:371-384

> Hochard S, Pinazo C, Grenz C, Burton Evans JL, Pringault O (2010) Impact of microphytobenthos on the sediment biochemical cycles: a modeling approach. Ecol Modell 221: 1687-1701

> Holling CS (1973) Resilience and stability of ecological systems. J Annu Rev Ecol Syst 4:1-23

> Jönsson B, Sundbäck K, Nilsson C (1994) An upright life form of an epipelic motile diatom - on the behaviour of Gyrosigma balticum. Eur J Phycol 29:11-15

> Larson F, Sundbäck K (2008) Role of microphytobenthos in recovery of functions in a shallow-water sediment system after hypoxic events. Mar Ecol Prog Ser 357:1-16

> Larson FRM, Petersen DG, Dahllöf I, Sundbäck K (2007) Combined effects of an antifouling biocide and nutrient status on a shallow-water microbenthic community. Aquat Microb Ecol 48:277-294

Lorenzen CJ (1967) Determination of chlorophyll and pheopigments: spectrophotometric equations. Limnol Oceanogr 12:343-346

Lundquist CJ, Thrush SF, Oldman JW, Senior AK (2004) Limited transport and recolonization potential in shallow tidal estuaries. Limnol Oceanogr 49:386-395

McArdle BH, Anderson MJ (2001) Fitting multivariate models to community data: a comment on distance based redundancy analysis. Ecology 82:290-297

> Miller DC, Muir CL, Hauser OA (2002) Detrimental effects of sedimentation on marine benthos: What can be learned from natural processes and rates? Ecol Eng 19: 211-232

> Montserrat F, Van Colen C, Degraer S, Ysebaert T, Herman PMJ (2008) Benthic community-mediated sediment dynamics. Mar Ecol Prog Ser 372:43-59

> Newell RC, Hitchcock DR, Seiderer LJ (1999) Organic enrichment associated with outwash from marine aggregates dredging: a probable explanation for surface sheens and enhanced benthic production in the vicinity of dredging operations. Mar Pollut Bull 38:809-818

Nielsen LP (1992) Denitrification in sediment determined from nitrogen isotope pairing. FEMS Microbiol Ecol 86: $357-362$

Norkko A, Rosenberg R, Thrush SF, Whitlatch RB (2006) Scale- and intensity disturbance determines the magnitude of opportunistic response. J Exp Mar Biol Ecol 330: 195-207

> Paerl HW, Pinckney JL (1996) A mini-review of microbial consortia: their roles in aquatic production and biogeochemical cycling. Microb Ecol 31:225-247

> Parodi ER, de Cao SB (2002) Benthic microalgal communities in the inner part of the Bahía Blanca estuary (Argentina): a preliminary qualitative study. Oceanol Acta 25:279-284

> Paterson DM (1986) The migratory behaviour of diatom assemblages in a laboratory tidal micro-ecosystem examined by low temperature scanning electron microscopy. Diatom Res 1:227-239

Perkins RG, Honeywill C, Consalvey M, Austin HA, Tolhurst TJ, Paterson DM (2003) Changes in microphytobenthic chlorophyll $a$ and EPS resulting from sediment compaction due to de-watering: opposing patterns in concentration and content. Cont Shelf Res 23:575-586

> Petersen DG, Sundbäck K, Larson F, Dahllöf I (2009) Pyrene toxicity depends on the nutrient status of the sediment community: implications for risk assessment. Aquat Toxicol 95:37-43

> Piehler MF, Winkelmann V, Twomey LJ, Hall NS, Currin CA, Paerl HW (2003) Impacts of diesel fuel exposure on the microphytobenthic community of an intertidal sand flat. J Exp Mar Biol Ecol 297:219-237

> Pimm S (1984) The complexity and stability of ecosystems. Nature 307:321-326

> Risgaard-Petersen N (2003) Coupled nitrification-denitrification in autotrophic and heterotrophic estuarine sediments: on the influence of benthic microalgae. Limnol Oceanogr 48:93-105

Rodil IF, Lohrer AM, Chiaroni LD, Hewitt JE, Thrush SF (2011) Disturbance of sandflats by thin terrigenous sediment deposits: consequences for primary production and nutrient cycling. Ecol Appl 21:416-426

Rossi F, Vos M, Middelburg JJ (2009) Species diversity and microbial carbon flow in reassembling macrobenthic communities. Oikos 118:503-512

Schratzberger M, Rees HL, Boyd SE (2000) Effects of simulated deposition of dredged material on structure of nematode assemblages — the role of burial. Mar Biol 136: 519-530

Söderqvist T, Eggert H, Olsson B, Soutukorva A (2005) Economic valuation for sustainable development in the Swedish coastal zone. Ambio 34:169-175

> Stocks KI, Grassle JF (2001) Effects of microalgae and food limitation on the recolonization of benthic macrofauna into in situ saltmarsh-pond mesocosms. Mar Ecol Prog Ser 221:93-104

Strickland JD, Parsons TR (1972) A practical handbook of seawater analysis. Bull Fish Res Board Can 167:310

Sundbäck K, Jönsson B, Nilsson P, Lindström I (1990) Impact of accumulating drifting macroalgae on a shallow-water sediment system: an experimental study. Mar Ecol Prog Ser 58:261-274

> Sundbäck K, Miles A, Hulth S, Pihl L, Engström P, Selander E, Svenson A (2003) Importance of benthic nutrient regeneration during initiation of macroalgal blooms in shallow bays. Mar Ecol Prog Ser 246:115-126

Sundbäck K, Linares F, Larson F, Wulff A, Engelsen A (2004) 
Benthic nitrogen fluxes along a depth gradient in a microtidal fjord: role of denitrification and microphytobenthos. Limnol Oceanogr 49:1095-1107

Sundbäck K, Miles A, Llnares, F (2006) Nitrogen dynamics in non-tidal littoral sediments: role of microphytobenthos and denitrification. Estaries Coasts 29: 1196-2011

Sundbäck K, Petersen DG, Dahllöf I, Larson F (2007) Combined nutrient-toxicant effects on a shallow-water sediment system: sensitivity and resilience of ecosystem functions. Mar Ecol Prog Ser 330:13-20

Sundbäck K, Alsterberg C, Larson F (2010) Effects of multiple stressors on shallow-water sediments: response of microalgae and meiofauna to nutrient-toxicant exposure. J Exp Mar Biol Ecol 388:39-50

Sutherland TF, Amos CL, Grant J (1998) The effect of buoyant biofilms on the erodibility of sublittoral sediments of a temperate microtidal estuary. Limnol Oceanogr 43: 225-235

Thrush SF, Hewitt JE, Norkko A, Cummings VJ, Funnell GA (2003) Macrobenthic recovery processes following catastrophic sedimentation on estuarine sandflats. Ecol Appl 13:1433-1455

Thrush S, Hewitt J, Cummings V, Ellis J, Hatton C, Lohrer A, Norkko A (2004) Muddy waters: elevating sediment input to coastal and estuarine habitats. Front Ecol Environ 2:299-306

Editorial responsibility: Ronald Kiene, Mobile, Alabama, USA
Thrush SF, Halliday J, Hewitt JE, Lohrer AM (2008) The effects of habitat loss, fragmentation, and community homogenization on resilience in estuaries. Ecol Appl 18: $12-21$

> Thrush SF, Hewitt JE, Dayton PK, Coco G and others (2009) Forecasting the limits of resilience: integrating empirical research with theory. Proc Biol Sci 276:3209-3217

Underwood AJ (1997) Experiments in ecology: their logical design and interpretation using analysis of variance. Cambridge University Press, Cambridge

Underwood GJC, Kromkamp J (1999) Primary production by phytoplankton and microphytobenthos in estuaries. Adv Ecol Res 29:93-153

- Underwood GJC, Paterson DM (1993) Recovery of intertidal benthic diatoms after biocide treatment and associated sediment dynamics. J Mar Biol Assoc U K 73:25-45

> Underwood GJC, Smith DJ (1998) Predicting epipelic diatom exopolymer concentrations in intertidal sediments from sediment chlorophyll a. Microb Ecol 35:116-125

> Wulff A, Sundbäck K, Nilsson C, Carlson L, Jönsson B (1997) Effect of sediment load on the microbenthic community of a shallow-water sandy sediment. Estuaries 20:547-558

> Yallop ML, Dewinder B, Paterson DM, Stal LJ (1994) Comparative structure, primary production and biogenic stabilization of cohesive and noncohesive marine sediments inhabited by microphytobenthos. Estuar Coast Shelf Sci 39:565-582

Submitted: March 11, 2011; Accepted: November 8, 2011 Proofs received from author(s): January 29, 2012 